\title{
Assessment of Toxic Metals in Some Selected Cosmetic Products in Nigeria and their Health Risks
}

\author{
OLAYINKA ABIDEMI IBIGBAMI ${ }^{*}$, SAMUEL OLUYEMI ADEFEMI ${ }^{1}$, \\ SAMUEL SUNDAY ASAOLU ${ }^{1}$, ISEOLUWA JOSHUA OREGE ${ }^{1,2}$, \\ ADEOLU JONATHAN ADESINA ${ }^{1}$, OLUGBENGA KAYODE POPOOLA ${ }^{1}$, \\ MAYOWA AKEEM AZEEZ1 ${ }^{1}$, ABIODUN FOLASADE AKINSOLA ${ }^{1}$, \\ RAUF ABIOYE OLATOYE ${ }^{1}$ \\ ${ }^{1}$ Department of Chemistry, Ekiti State University, PMB 5363 Ado-Ekiti, Nigeria \\ ${ }^{2}$ Dalian National Laboratory for Clean Energy, Dalian Institute of Chemical Physics-Chinese Academy of Sciences, \\ 116023, Dalian, China
}

\begin{abstract}
The study determined the levels of heavy metals in some selected cosmetic products, commonly marketed in Nigeria, and assessed their possible potential human health risks. The health risk assessment was patterned according to the model of the United States Environmental Protection Agency (USEPA). The heavy metals concentrations ranged from $0.043 \pm 0.027(\mathrm{~Pb})-1.89 \pm 1.04(\mathrm{Fe})$ with the concentration order: $\mathrm{Fe}>\mathrm{Cu}>\mathrm{Zn}>\mathrm{Mn}>\mathrm{Cr}>\mathrm{Cd}>\mathrm{Pb}$. The total daily intake for all the metals were generally below maximum tolerable daily intake (MTDI). The estimated hazard index, hazard quotient and cancer risks were all within allowable level. The study indicated that users of the studied products are less susceptible to any significant health (carcinogenic or non-carcinogenic) risk.
\end{abstract}

Keywords: Heavy metals, cosmetics, risk assessment, carcinogenic, non-carcinogenic, health risk

\section{Introduction}

Personal care products (PCPs) are substances applied to enhance physical outlook or prevent human body odour [1,2]. They are promoted globally due to quest for physical beauty by people [3] as well as to cover flaws on human skin. In most African countries, female are the commonest user of personal care products (PCPs). Although in recent times, male are gradually using them to improve their facial appearances [4]. However, the growing concerns associated with the use of these products have necessitated continuous monitoring to ensure that the constituents of the products are within acceptable limits [5]. Prolong duration or continuous use of PCPs on human body surface, especially under hot humid condition, exposes users to different hazardous chemicals and thus enhances their percutaneous absorption. Heavy metals and radioactive elements are some of the contents, which have been detected in many PCPs [6-8]. They are naturally present in air, soil, rocks and water and can be discovered in PCPs through raw materials used in manufacturing them [9].

Heavy metals are group name for metals and non-metals (metalloids) associated with contamination, potential toxicity or eco-toxicity [4]. They have been known to be present in varying concentrations in many PCPs including lipsticks, eye shadow, powder, cream, lip gloss, brow pencil etc. $[10-12]$. It is suggested that cosmetics should not contain elements such as arsenic, cadmium, lead, mercury, beryllium, selenium [8]. However, some metals, such as cadmium and lead, can be released by metal components used in the technological processes of cosmetic products [6]. At low concentration, they can cause damage to internal body organ of human [11] and at high concentration, they pose serious imminent human health problems such as vomiting, cramps, convulsions, cardiovascular, kidney, nervous and bone diseases [13-16]. Their implications can be deadly. According to Health Canada [17], 100\% of personal care products investigated had Nickel and over $90 \%$ tested had both lead and beryllium and on the average contained at least four of the eight metals of concern, which include arsenic, cadmium, lead, mercury, beryllium, nickel, selenium and thallium.

\footnotetext{
$\overline{\text { *email:olayinkaibigbami@yahoo.co.uk }}$
} 
Some of these heavy metals are intentionally incorporated as ingredient during manufacturing of PCPs [18]. For example, press powder for eye shadows main ingredients are talc with pigment and zinc or magnesium stearate used as binder [6], iron oxide and some aluminium compounds are used as colourants for eye shadows and nail polishes respectively [19). Some studies have revealed the association between some ingredients of personal care products and various health problems [12, 2022] and usually female are at greater risk. With the hazard associated with them, some of these metals have been banned as intentional ingredients in PCPs [23]. For instance, in Canada, arsenic, cadmium, mercury, lead, beryllium, selenium and thallium have been banned as ingredients in PCPs [24]. Trace metals are one of the most persistent pollutant in waste water. The contamination of aquatic ecosystems with a wide range of pollutants especially heavy metals cause direct toxic effects and has become a matter of general concern throughout the last decades [25]. The discharge of wastewater containing high amounts of heavy metals from cosmetic products into water bodies leads to several environmental and health impacts. Some of the negative impacts of heavy metals to aquatic ecosystems include death of aquatic life, alga booms, habit destruction, increased water flow, other short and long term toxicity from chemical contaminants.

In spite of the attention received over the years on the effect of heavy metal hazard in personal care products [26], very little attention has been given to human exposure to heavy metals in cosmetic as well as their potential human health risk. Up till date, there are scarce data on the permissible limit for concentration of heavy metals in PCPs. Human health risk assessment of heavy metals gives useful information on threat regarding toxic metals in PCPs. This work is, therefore, aimed at determining the levels of heavy metals in some selected personal care products commonly marketed in Nigeria and assessing their health risk on human body surface. The growing interest in personal care products and lack of regulations in their usage has necessitated this study, as it will provide scientific data on the levels of toxic metals to which an average user of PCPs may be exposed.

\section{Materials and methods}

\section{Sample collection and pre-treatment}

Ten (10) different samples of sealed cosmetic products commonly sold in Ado-Ekiti modern market in Nigeria were purchased. The criterion for selection of the brands was based on the makeup used by all socio-economic groups in Nigeria. Solid samples were grounded to fine powder and stored in a cool dry place prior to analysis. The cosmetic products collected were 5 powders (IMU=Iman make up, $\mathrm{PCF}=$ Proconcealer foundation, $\mathrm{SKF}=$ Sleek foundation, $\mathrm{COC}=$ Corrector and concealer and $\mathrm{NBB}=$ Nude beyounce beauty), 2 lip gloss (LGR= Lip gloss romantic and WLA= Wet Lip absolute) and 3 eyeliners $(\mathrm{AEL}=\mathrm{Absolute}$ eyeliner, $\mathrm{DHM}=$ Dulhan mascara and $\mathrm{ES}=$ Eye shadow)

\section{Sample digestion and analysis}

One $(1 \mathrm{~g})$ each of the grinded samples was weighed into a clean Teflon beaker and digested for about 2-3 $\mathrm{h}$ using aqua regia $\left(\mathrm{HNO}_{3}: \mathrm{HCl} ; 1: 3\right)$. After digestion and cooling, the solution was filtered through a Whatman filter to remove insoluble particles and brought to a final volume of $100 \mathrm{~mL}$ with deionized water. These solutions were transferred to plastic bottles and were kept in a refrigerator until ready for analysis. Analysis of filtrates using Atomic Absorption Spectrophotometer (PG 990) available at the Centre for Energy Research and Development, Obafemi Awolowo University, Ile-Ife, Nigeria. Each sample was analysed in triplicate, and reagent blank determination was performed to ascertain that no impurity was introduced during extraction procedure.

\section{Human risk assessment}

Available daily Intake (ADI) of various heavy metals in the personal care products (PCPs) and their health risk indices were used to estimate the adverse human health effects associated with the extent of exposure from the cosmetic products. The average daily intake (ADI) of heavy metals in 
PCPs were determined via dermal absorption using the formula in Equation 1 as recommended by Liang et al. [27].

$$
\mathrm{ADI}=\frac{\mathrm{Cm} \times \mathrm{AF} \times \mathrm{SA} \times \mathrm{ABS} \times \mathrm{EF} \times \mathrm{ED} \times \mathrm{CF}}{\mathrm{BW} \times \mathrm{AT}}
$$

The equation links the average dose to the exposure medium concentration. ADI is measured in $\mathrm{mgkg}^{-1} \mathrm{day}^{-1}, \mathrm{Cm}=$ is the concentration of heavy metals $\left(\mathrm{mgkg}^{-1}\right)$ in the PCPs; AF is skin adherence factor $\left(\mathrm{mgcm}^{-2}\right)=0.07$ [28]; CF is conversion factor (years) $=26$ [28]; ED is the exposure duration $($ year $)=26,[29]$; EF is exposure frequency $\left(\right.$ day year $\left.^{-1}\right)=350$ [30]; BW is the average of human body weight of exposed population $(\mathrm{kg})=80$ [29]; SA is exposed surface area of skin $\left(\mathrm{cm}^{2}\right)=19652$ [29]; $\mathrm{ABS}$ is dermal adsorption factor $=0.1[28]$; and AT is average time (days) $=25500$ [31] .

\section{Non-carcinogenic risk}

The human health risk posed by the heavy metal exposure are usually characterized by hazard quotient [32], which is the ratio of average daily intake to the dermal reference dose of metal.

$$
H Q=\frac{A D I}{R_{f} D}
$$

The risk indices for non-carcinogenic substances were obtained using the formula given by the Equation 2, where ADI is the available daily intake and $\mathrm{R}_{\mathrm{f}} \mathrm{D}$ is the dermal reference dose of metal. If the value of $\mathrm{HQ}$ are less than one $(\mathrm{HQ}<1)$, it indicates no adverse effects on human health, on the other hand if $\mathrm{HQ}$ is greater than one $(\mathrm{HQ}>1)$, it indicates adverse health effects.

\section{Hazard index}

To assess the overall potential for health effect posed by more than one metal, combining HQs across metals can serve as a conservative assessment tool to estimate high-end risk rather than lowend risk to protect the public [33]. The combined hazard index indicates the interactive add/or additive effects upon the exposure of two or more heavy metals in the cosmetic products on the human body. The total risk of the metals studied was calculated using health risk index according to the formula in equation 3.

$$
H I=\sum \mathrm{HQ}=\frac{A_{1}}{D_{1}}+\frac{A_{2}}{D_{2}}+\cdots+\frac{A_{n}}{D_{n}}=\sum_{i=1}^{n} \frac{A_{i}}{D_{i}}
$$

where $\mathrm{HI}$ is the hazard index, HQ is the hazard quotient, A1, A2, An and Ai are the average daily intake (ADI) of each metal in a mixture of $n$ metals in the cosmetic products, whereas D1, D2 and Di are the dermal reference dose $\left(\mathrm{R}_{\mathrm{f}} \mathrm{D}\right)$ of each metal.

\section{Carcinogenic risks}

Carcinogenic risks estimate the probability of developing cancer upon exposure to carcinogenic contaminant over a lifetime [34]. It is calculated by multiplying available daily intake ADI with cancer slope factor (SF) as shown in equation 4.

$$
\text { Cancer risk }=\mathrm{ADI} \times \mathrm{SF}
$$

\section{Results and discussions \\ Concentration of heavy metals in the cosmetic products}

The concentrations of heavy metals in the selected cosmetic products are depicted in Table 1 . The results clearly showed variation in concentrations of the heavy metals. In general, the $\mathrm{Cd}(\mathrm{mg} / \mathrm{kg})$ 
ranged from 0.080 (WLA) - 0.240 (CDC); Cr 0.2 (COC) - 0.340 (NBB), Fe 0.11 (COC) - 3.38 (ES), Zn 0.072 (COC) - 0.932 (WLA), Pb 0.008 (COC) - 0.084 (IMU), Cu 0.040 (IMU) - 1.55 (SKF) and Mn 0.124 (COC) -0.300 (ES). Mean concentrations of the metals ranged from $0.043 \pm 0.027(\mathrm{~Pb})-$ $1.89 \pm 1.04(\mathrm{Fe})$ with the order of: $\mathrm{Fe}>\mathrm{Cu}>\mathrm{Zn}>\mathrm{Mn}>\mathrm{Cr}>\mathrm{Cd}>\mathrm{Pb}$ and $\mathrm{ES}>\mathrm{WLA}>\mathrm{NBB}>\mathrm{SKF}>\mathrm{LGR}>$ DHM $>$ AEL $>$ PCF $>$ IMU.

Table 1. Concentration $(\mathrm{mg} / \mathrm{kg})$ of some selected heavy metals in the studied samples

\begin{tabular}{|c|c|c|c|c|c|c|c|c|}
\hline Sample & \multirow{2}{*}{ Cd } & \multirow{2}{*}{$\mathbf{C r}$} & \multirow{2}{*}{$\mathrm{Fe}$} & \multirow{2}{*}{ Zn } & \multirow{2}{*}{$\mathbf{P b}$} & \multirow{2}{*}{$\mathrm{Cu}$} & \multirow{2}{*}{ Mn } & \multirow{2}{*}{$\begin{array}{l}\text { Total } \\
\text { metals }\end{array}$} \\
\hline Code & & & & & & & & \\
\hline \multicolumn{9}{|l|}{ Powder } \\
\hline IMU & 0.124 & 0.224 & 2.380 & 0.884 & 0.084 & 0.040 & 0.244 & 3.980 \\
\hline PCF & 0.092 & 0.204 & 1.820 & 0.844 & 0.040 & 1.250 & 0.208 & 4.458 \\
\hline SKF & 0.084 & 0.128 & 2.480 & 0.868 & 0.036 & 1.550 & 0.192 & 5.338 \\
\hline $\mathrm{COC}$ & 0.240 & 0.020 & 0.110 & 0.072 & 0.008 & 0.460 & 0.124 & 1.034 \\
\hline NBB & 0.156 & 0.340 & 2.640 & 0.696 & 0.048 & 1.280 & 0.288 & 5.448 \\
\hline \multicolumn{9}{|l|}{ Lip gloss } \\
\hline LGR & 0.096 & 0.252 & 2.100 & 0.833 & 0.044 & 1.370 & 0.218 & 4.913 \\
\hline WLA & 0.080 & 0.140 & 2.580 & 0.932 & 0.032 & 1.530 & 0.204 & 5.498 \\
\hline \multicolumn{9}{|l|}{ Eyeliners } \\
\hline $\mathrm{AEL}$ & 0.100 & 0.212 & 1.960 & 0.764 & 0.040 & 1.240 & 0.212 & 4.528 \\
\hline $\mathrm{DHM}$ & 0.112 & 0.192 & 2.060 & 0.852 & 0.040 & 1.230 & 0.22 & 4.706 \\
\hline ES & 0.168 & 0.320 & 3.380 & 0.688 & 0.048 & 1.200 & 0.300 & 6.104 \\
\hline
\end{tabular}

IMU=Iman make up; LGR= Lip gloss romantic; AEL=Absolute eyeliner; DHM=Dulhan mascara; $\mathrm{PCF}=$ Proconcealer foundation; $\mathrm{ES}=$ Eye shadow; $\mathrm{NBB}=$ Nude beyounce beauty; WLA= Wet lips absolute; $\mathrm{SKF}=\mathrm{Sleek}$ foundation; $\mathrm{COC}=\mathrm{Corrector}$ and concealer.

The results revealed high spatial variation in the metal concentration as revealed by the coefficient of variation $(\mathrm{CV})$, while the lip gloss and eyeliners revealed low spatial variation in most metals (Table 2). Fe showed the highest in all the sampled products except the corrector and concealer (COC) that reflected $\mathrm{Cu}$. The variability of the metals determined by the values of the coefficient of variation was the highest for $\mathrm{Cu}, \mathrm{Cr}$ and $\mathrm{Fe}$ in powders, lip gloss and eyeliners, respectively. Lowest degree of variation in the samples was observed in Mn for powders and lip gloss, while eyeliners reflected $\mathrm{Cu}$. Comparing the result from the present study with that of International Standards, the observed level of $\mathrm{Cd}$ and $\mathrm{Pb}$ were within the World Health Organization (WHO), European Union (EU) and United State (US) allowable or permissible limits in PCPs (Table 3). Cr also fell within the EU permissible limit $(1 \mathrm{mg} / \mathrm{kg})[35,36]$. Comparatively, high concentration $(\mathrm{mg} / \mathrm{kg})$ of $\mathrm{Cd}, 0.5-1.1,0.279-0.781$, 14.4 - 37.3, ND -36.3 and 0.14 - 14.28 were reported by Nnorom et al. [37], Ayenimo et al. [11], AlDayel et al. [12], Omenka and Adeyi [3] and Zafarzadeh et al. [38] as compared to the present study, while those reported by Khalid et al. [39], Chauhan et al. [40]; and Ekere et al. [41] for Cd were lower. The $\mathrm{Pb}(0.008-0.084 \mathrm{mg} / \mathrm{kg})$ were similar in some cases to what Ekere et al. [41] reported, while Nnorom [42], Chauhan et al. [40] and Ekere et al. [41] were higher than the present study. The concentration $(\mathrm{mg} / \mathrm{kg}) \mathrm{Zn}(0.07-0.93)$ was lower than $1.88-112,000,72.0-128.8$ and $0.539-1.104$ as reported by Omenka and Adeyi [3], Nnorom et al. [37] and Ayenimo et al. [11]. 
Table 2. Comparison of mean concentration $(\mathrm{mg} / \mathrm{kg}$ ), standard deviation (SD) and coefficient of variation $(\mathrm{CV} \%)$ of heavy metals in the various PCPs studied

\begin{tabular}{lccccccc}
\hline $\begin{array}{l}\text { Sample } \\
\text { Code }\end{array}$ & $\mathrm{Cd}$ & $\mathrm{Cr}$ & $\mathrm{Fe}$ & $\mathrm{Zn}$ & $\mathrm{Pb}$ & $\mathrm{Cu}$ & $\mathrm{Mn}$ \\
\hline Powders (n=5) & $0.139 \pm 0.063$ & $0.183 \pm 0.119$ & $1.89 \pm 1.04$ & $0.673 \pm 0.344$ & $0.043 \pm 0.027$ & $0.916 \pm 0.637$ & $0.211 \pm 0.061$ \\
& $(45.3)$ & $(65.0)$ & $(55.1)$ & $(51.1)$ & $(62.8)$ & $(69.5)$ & $(28.9)$ \\
Lip gloss (n=2) & $0.088 \pm 0.011$ & $0.916 \pm 0.079$ & $2.34 \pm 0.339$ & $0.883 \pm 0.070$ & $0.038 \pm 0.008$ & $1.45 \pm 0.113$ & $0.211 \pm 0.010$ \\
& $(12.5)$ & $(40.3)$ & $(14.5)$ & $(7.90)$ & $(21.1)$ & $(7.80)$ & $(4.70)$ \\
Eyeliners (n=3) & $0.127 \pm 0.036$ & $0.241 \pm 0.069$ & $2.47 \pm 0.793$ & $0.768 \pm 0.082$ & $0.042 \pm 0.005$ & $1.22 \pm 0.021$ & $0.224 \pm 0.049$ \\
& $(28.3)$ & $(28.6)$ & $(32.1)$ & $(10.7)$ & $(11.9)$ & $(1.70)$ & $(21.9)$ \\
\hline
\end{tabular}

Mean \pm SD $(\mathrm{CV} \%)$

Table 3. Comparison of some metals $(\mathrm{mg} / \mathrm{kg})$ determined in this study with international allowable limits in PCPs

\begin{tabular}{|l|c|c|c|c|c|c|}
\hline & $\mathrm{Cd}$ & $\mathrm{Zn}$ & $\mathrm{Pb}$ & $\mathrm{Fe}$ & $\mathrm{Cu}$ & $\mathrm{Cr}$ \\
\hline Present study & $0.088-0.139$ & $0.673-0.883$ & $0.038-0.043$ & $1.89-2.340$ & $0.122-1.450$ & $0.183-0.916$ \\
\hline WHO, Health Canada & $0.500, \quad 5.000$ & - & $10.000, \quad 10.000$ & - & - & - \\
\hline EU, US & $0.500,0.080$ & - & $0.500,10.000$ & - & - & 1.000, \\
\hline Germany & 0.100 & - & 1.000 & - & - & - \\
\hline
\end{tabular}

\section{Estimation of the calculated available daily intake}

Figure 1 showed the available daily intake of heavy metals in the cosmetic products. The degree of toxicity of heavy metals to humans depends on their daily intake [43]. The calculated available daily intake ranged from $4.910 \times 10^{-8}(\mathrm{~Pb}, \mathrm{COC})-2.071 \times 10^{-8}(\mathrm{Fe}, \mathrm{ES})$. The total daily intake for all the metals were generally below maximum tolerable daily intake (MTDI) of 0.210, 0.021 and 0.200 for $\mathrm{Pb}, \mathrm{Cd}$ and $\mathrm{Cr}$, respectively.

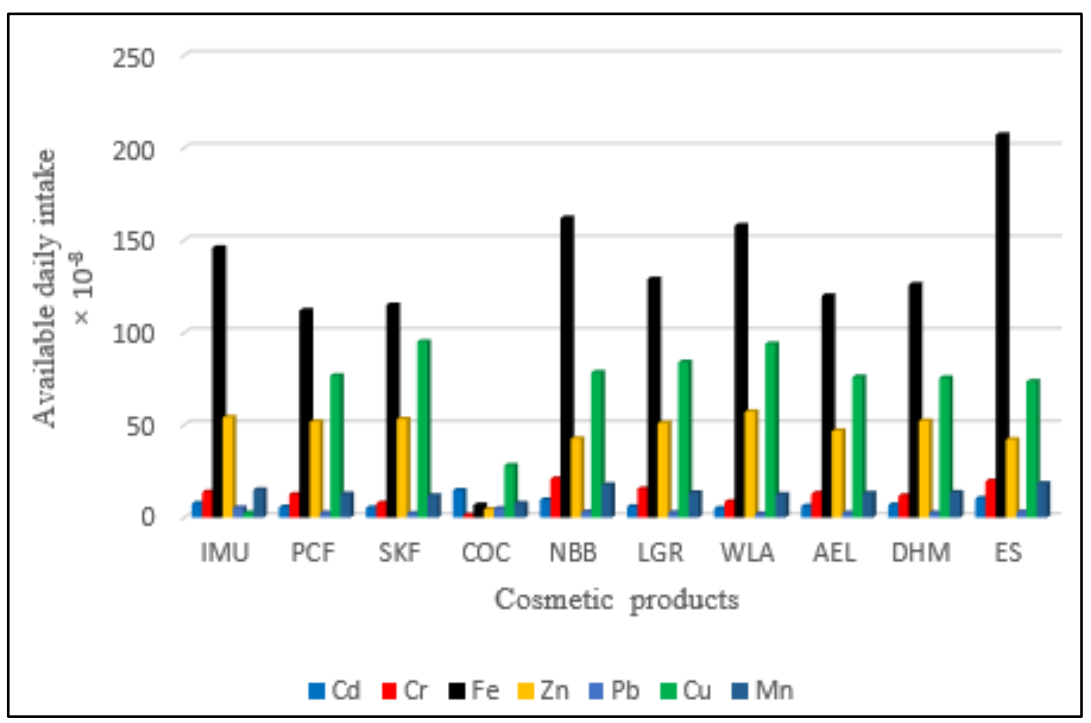

Figure 1. Estimated available daily intake (ADI) of the metals in PCPs

\section{Non-carcinogenic risk assessment}

To assess the non-carcinogenic risk of the studied metals on human via dermal adsorption, the hazard quotient (HQ) and hazard index (HI) were used. The HQ, which is the ratio of determined dose of a pollutant to a reference dose level. If $\mathrm{HQ}>1$, the exposed population will likely experience a detrimental effect [44]. Table 4 showed the HQ and HI of heavy metals in the collected cosmetic products. The calculated HQ ranged from $3.730 \times 10^{-7}$ to $1.390 \times 10^{-2}$ and thus showed that metal HQ < 1 in all samples. This observation therefore revealed that users of studied cosmetic products in Nigeria would not experience any significant non-carcinogenic health risk via dermal adsorption. The HI values in all the products were also less than 1, indicating no concern for overall potential health risks (non-carcinogenic). 


\section{Carcinogenic risk assessment}

Table 5 showed the carcinogenic risk values for lead, cadmium and chromium. The cancer risk values ranged from $4.17 \times 10^{-11}-8.97 \times 10^{-7}$ with cadmium showing the highest contribution in all cases.

Table 4. Hazard quotient (HQ) and hazard index (HI) of heavy metals in collected cosmetic products

\begin{tabular}{lccccccc}
\hline $\begin{array}{l}\text { Sample } \\
\text { Code }\end{array}$ & $\begin{array}{c}\mathbf{C d} \\
\left(\mathbf{1 0}^{-\mathbf{2}}\right)\end{array}$ & $\begin{array}{c}\mathbf{C r} \\
\left(\mathbf{1 0}^{-\mathbf{2}}\right)\end{array}$ & $\begin{array}{c}\mathbf{F e} \\
\left(\mathbf{1 0}^{-\mathbf{4}}\right)\end{array}$ & $\begin{array}{c}\mathbf{P b} \\
\left(\mathbf{1 0}^{-4}\right)\end{array}$ & $\begin{array}{c}\mathbf{C u} \\
\left(\mathbf{1 0}^{-\mathbf{4}}\right)\end{array}$ & $\begin{array}{c}\text { Mn } \\
\left(\mathbf{1 0}^{-4}\right)\end{array}$ & $\begin{array}{c}\text { HI } \\
\left(\mathbf{1 0}^{-\mathbf{2}}\right)\end{array}$ \\
\hline IMU & 0.76 & 0.91 & 0.30 & 0.90 & 0.02 & 0.80 & 1.07 \\
PCF & 0.57 & 0.83 & 0.20 & 0.50 & 0.60 & 0.70 & 1.42 \\
SKF & 0.52 & 0.52 & 0.30 & 0.40 & 0.80 & 0.60 & 1.10 \\
COC & 1.47 & 0.08 & 0.01 & 0.09 & 0.20 & 0.40 & 1.60 \\
NBB & 0.96 & 1.39 & 0.40 & 0.60 & 0.60 & 0.90 & 2.40 \\
LGR & 0.59 & 1.02 & 0.30 & 0.50 & 0.70 & 0.70 & 1.60 \\
WLA & 0.49 & 0.57 & 0.40 & 0.40 & 0.80 & 0.70 & 1.10 \\
AEL & 0.61 & 0.87 & 0.30 & 0.50 & 0.60 & 0.70 & 1.50 \\
DHM & 0.69 & 0.79 & 0.30 & 0.50 & 0.60 & 0.70 & 1.50 \\
ES & 0.10 & 1.31 & 0.50 & 0.60 & 0.60 & 1.00 & 2.40 \\
\hline
\end{tabular}

Rfd for $\mathrm{Cu}=0.012 \mathrm{mg} / \mathrm{kg} /$ day, $\mathrm{Pb}=0.000525 \mathrm{mg} / \mathrm{kg} / \mathrm{day}, \mathrm{Cd}=0.00001 \mathrm{mg} / \mathrm{kg} / \mathrm{day}$ [29]; $\mathrm{Cr}=0.000015 \mathrm{mg} / \mathrm{kg} / \mathrm{day}$ [45]; $\mathrm{Mn}=0.0056 \mathrm{mg} / \mathrm{kg} / \mathrm{day} ; \mathrm{Fe}=0.045 \mathrm{mg} / \mathrm{kg} /$ day $[46,47]$.

Table 5. Carcinogenic risk of heavy metals for dermal exposure via the PCPs samples

\begin{tabular}{lccc}
\hline & Cd & Cr & Pb \\
\hline IMU & $4.64 \mathrm{E}-7$ & $6.85 \mathrm{E}-8$ & $4.38 \mathrm{E}-10$ \\
PCF & $3.45 \mathrm{E}-7$ & $6.25 \mathrm{E}-8$ & $2.08 \mathrm{E}-10$ \\
SKF & $3.14 \mathrm{E}-7$ & $3.93 \mathrm{E}-8$ & $1.88 \mathrm{E}-10$ \\
COC & $8.97 \mathrm{E}-7$ & $6.15 \mathrm{E}-9$ & $4.17 \mathrm{E}-11$ \\
NBB & $5.84 \mathrm{E}-7$ & $1.05 \mathrm{E}-7$ & $2.51 \mathrm{E}-10$ \\
LGR & $3.59 \mathrm{E}-7$ & $7.75 \mathrm{E}-8$ & $2.30 \mathrm{E}-10$ \\
WLA & $3.00 \mathrm{E}-7$ & $4.30 \mathrm{E}-8$ & $1.67 \mathrm{E}-10$ \\
AEL & $3.75 \mathrm{E}-7$ & $6.50 \mathrm{E}-8$ & $2.08 \mathrm{E}-10$ \\
DHM & $4.19 \mathrm{E}-7$ & $5.90 \mathrm{E}-8$ & $2.08 \mathrm{E}-10$ \\
ES & $6.28 \mathrm{E}-7$ & $9.8 \mathrm{E}-8$ & $2.51 \mathrm{E}-10$ \\
\hline SF $(\mathrm{Cu})=$ N/A; SF $(\mathrm{Pb})=0.0085 ; \mathrm{SF}(\mathrm{Cd})=6.1[31]$ \\
Cr $=0.5$ (CALEPA) CALEPA= California Environmental \\
Protection Agency, US
\end{tabular}

The United State Environmental Protection Agency (US EPA) considers cancer risk in the range of $1 \times 10^{-6}-1 \times 10^{-4}$ as acceptable for regulatory purposes [28]. The result showed no concern for possible potential carcinogenic risk via dermal exposure to the cosmetic products.

\section{Conclusions}

This study affirm the presence of toxic metals with varying concentrations in the studied cosmetic products commonly marketed in Nigeria. However, the estimated hazard index, hazard quotient and cancer risks were all within allowable levels. The study showed no evident of likely potential noncarcinogenic health risks via exposure to the cosmetic products. It also evidently established that carcinogenic effect cannot be experienced with exposure to the studied cosmetic products. However, there is need for strict regulations and standard as well as continuous monitoring in Nigeria to curb spuriousness of known brands of cosmetic products as well as to educate their users about the adverse health effects posed by heavy metal accumulation. 
Acknowledgement: The authors appreciate the technical assistance rendered by Centre for Energy Research and Development, Obafemi Awolowo University, Ile-Ife.

\section{References}

1.LOPACIUK, A.; LOBODA, M. In proceedings of the management, knowledge and learning international conference, Zadar, Crotia, 2013, p. 19.

2. ALSAFFAR, N.M., HUSSEIN, H.J., J. Envron. Sci. Toxicol. Food Technol., 8, 2014, p. 9.

3.OMENKA, S. S., ADEYI, A. A., Toxicology Reports 3, 2016, p. 628.

4.FARURUWA, M.D., BARTHOLOMEW, S.P., Am. J. Chem. Appl., 1, nr. 2, 2014, p. 27.

5.IGWE-EZIKPE, M.N., OLASORO, H.S.A., OSUALA, F.I., OBIDI, O.F., AYANSHINA, O.A., TAIWO, F.O., SOTINALA, O.T., Nigeria Society Experi. Biol., 29, nr. 3, 2017, p. 110.

6.VOLPE, M.G., NAZZARO, M., COPPOLA, R., RAPUANO, F., AQUINO, R.P., MicroChem. J., 101, 2012, p. 65.

7.MAYILDURAI, R., RAMASUBBU, A., VELMANI, N., J. Pharm. Res., 9, 2015, p. 27.

8.NOUIOUI, M.A., MAHJOUBI, S., GHORBEL, A., YAHIA, M.B.H., AMIA, D., GHORBEL, H., HEDHILI, A., Int. Sch. Res. 2016, p. 629.

9.PASCU, D. E., MIRON, A. R.; PASCU-NEAGU, M., AURELIA, C. N; EUGENIA, E. T., Separat. Sci. Tech., 51, nr. (15-16), 2016, P. 2628.

10.AL-SALEH, I., AL-ENAZI, S., SHINWARI, N., Regul. Toxicol. Pharmacol., 54, 2009, p. 105.

11.AYENIMO, J.G., YSUF, A.M., ADEKUNLE, A.S., MAKINDE, O.W., Bull. Environ. Contam. Toxicol., 84, 2010, p. 8.

12.AL-DAYEL, O., HEFNE, J., AL-AJYAN, T. Orient. J. Chem., 27, 2011, p.1.

13.NAMASIVAYAM, C., KADIRVELU, K., Carbon, 37, 1999, p. 79.

14.PAULINO, A.T., MINASSE, F.A.S., GUILHERME, M.R., REIS, A.V., MUNIZ, E.C., NOZAKI, J. J., Colloid Interface Sci., 301, 2006, p. 487.

15.OYARO, N., JUDDY, O., MURAGO, E.N.M., GITONGA, E., Int. J. Food Agric. Environ., 5, 2007, p.119.

16.ADEKUNLE, A. S.; OYEKUNLE, J.A.O.; BARUWA, S.O.; OGUNFOWOKAN, A.O.; EBENSO, E.E. Toxicol. Rep., 2014, p. 243.

17.***Health Canada, 2011. Cosmetic ingredient hot list. Available at:<http://www.hc-sc.gc.ca/cps8pc/alt_formats/hecs-sesc/pdf/cosmet_person/indust/hot-list-critique/hotlist-liste_2011-eng.pdf.

18.OMOLAOYE, J.A., UZAIRU, A., GIMBA, C.E., Arch. Appl. Sci. Res., 2, 2010, p.76.

19.***Campaign for Safe Cosmetics, lead in lipstick, 2007

http://www.safecosmetics.org/article.php?id=223

20.LORETZ, L.J., API, A.M., BARRAJ, L.M., BURDICK, K.J., DAVIS, D.A., DRESSLER, W., GILBERT, E., JARRET, G., MANN, S., PAN, I., RE, T., RENSKERS, K., SCRAFFORD, C., VATER, S., Food Chem. Toxicol,, 44, 2006, p. 2008.

21.FORTE, G., PETRUCCI, F., BOCCA, B., Inflammation Allergy Drug Targets, 7, 2008, p. 145.

22.MURPHY, T., DARELL, G.S., KIM, I., KOM, S., Hum. Ecol. Risk Assess. 15, nr. 6, 2009, p. 1286.

23.KUMAR, M., FURUMAI, H., KURISU, F., KASUGA, I., Geoderma, 211-212, 2013, p. 8.

24.***Environmental Defence Canada. Heavy metal hazard. The health risks of hidden heavy metals in face makeup. Environmental Defence, Toronto, Canada. 2011. Available at:

<http: //environmentaldefence.ca/sites/default/fices/report_files/heavymetalhazardand\%20FINAL.pdf. 25.IONESCU, P., DEAK, G., DIACU, E., RADU, V.M., Rev. Chim. 67(11), 2016, 2148.

26.ABDEL-FATTAH, A., PINGITORE, N.E. Jr., Environ. Geochem. Health, 31, 2009, p. 487.

27.LIANG, Y., YI, X., DANG, Z., WANG, Q., LUO, H., TANG, J., Int. J. Environ. Res. Public Health, 14, nr. 12, 2017, p. 1557. 
28.***U.S. ENVIRONMENTAL PROTECTION AGENCY. Risk Assessment Guidance for Superfund Volume 1: Human Health Evaluation Manual (Part E, Supplemental Guidance for Dermal Risk Assessment) USEPA: Washington, DC, USA, 2004.

29.***UNITED STATES ENVIRONMENTAL PROTECTION AGENCY. Exposure Factors Handbook Edition (Final); Office of Emergency and Remedial Response: Washington, DC, USA, 2011.

30.***U.S. ENVIRONMENTAL PROTECTION AGENCY. Human Health Evaluation Manual, Supplemental Guidance: Standard Default Exposure Factors. USEPA, Washington, DC, USA, 1991. 31.***DEPARTMENT OF ENVIRONMENTAL AFFAIRS. The Framework for the Management of Contaminated Land, South Africa. Available online:http://sawic.environment.gov.za/documents/562.pdf.

32.***USEPA, Risk assessment guidance for Superfund volume 1: human health evaluation manual (Part A). EPA/540/1-89/002. Washington, D. C.: Environmental Protection Agency, United States, 1989.

33.QU, C.S., MA, Z-W., YANG, J., LIU, Y., BI, J., HUANG, L., 7, no. 11, 2012, p. 1.

34.TITILAYO, Y., ADENIJI, A., ADENIJI, M., OKOH, A., Chemosphere, 211, 2018, 834-843.

35.SUKENDER, K., JASPREET S., SNEHA, D., MUNISH, G., Res. J. Chem Sci., 2, nr.3, 2012, p.46. 36.UMAR, M.A., CALEB, H., Int. J. Res. Cosmet. Sci., 3, nr. 2, 2013, p. 14.

37.NNOROM, I.C., IGWE, J.C., OJI-NNOROM, C.G., Afr. J. Biotechnol., 4, nr. 10, 2005, p. 1133.

38.ZAFARZADEH, A., SHAHRYARI, A., TAZIKI, S., AHMADI, N., MIRKARIMI, K., CHARKAZI, A., National J. Physiol., Pharm. Pharmacol., 8, nr. 8, 2018, p.1200.

39.KHALID, A., BUKARI, I.H., RIAZ, M., REHMAN, G., AIN, Q.U., BOKHARI, T.F., RASOOL, N., ZUBAIR, M., MUNIR, S., Int. J. Biol. Pharm. Allied Sci., 2, nr.5, 2013, p. 1003.

40.CHAUHAN, S.B., CHANDAK, A., AGRAWAL, S.S., Int. J. Adv. Res., 2, nr. 4, 2014, p. 257.

41.EKERE, N.R., IHEDIOHA, J.N., OPARANNOZIE, T.I., OGBUEFI, F.I., AYOGU, J. J., Chem. Phar. Res., 6, nr. 8, 2014, p. 561.

42.NNOROM, I.C., Tocicol. Environ. Chem., 93, nr. 5/6, 2011, p. 1135.

43.ULLAH, A.K.M.A.; AKTER, M.; MUSARRAT, M.; QURAISHI, S.B., Biol. Trace Elem. Res., 190, nr. 2, 2018, p. 283.

44.ULLAH A.K.M.A., MAKSUD M.A., KHAN S.R., LUTFA, L.N., QURAISHI SB., Toxicol Rep., 4, 2017, p. 574.

45.***USEPA, Risk based screening table http://wwwzepagov/risk based screening table generic tables, 2015.

46.FAIRBROTHER, A., WENSTEL, R., SAPPINGTON, K., WOOD, W., Ecotoxicol. Environ. Saf., 68, 2007, p. 145.

47.ODUKOYA, A.M., OBANIYI, S.B., OLUSEYI, T.O., ADEYEYE, O.A., Environ. Nanotechnol. Monit. Manag., 8, 2017, p. 290

Manuscript received: 04.04.2020 